University of Nebraska - Lincoln

DigitalCommons@University of Nebraska - Lincoln

Publications from USDA-ARS / UNL Faculty

U.S. Department of Agriculture: Agricultural

Research Service, Lincoln, Nebraska

2005

\title{
Plant-to-Plant Variability in Corn Production
}

\author{
K. L. Martin \\ Oklahoma State University - Main Campus \\ P. J. Hodgen \\ USDA-ARS \\ K. W. Freeman \\ Oklahoma State University - Main Campus \\ Ricardo Melchiori \\ INTA \\ D. B. Arnall \\ Oklahoma State University - Main Campus
}

See next page for additional authors

Follow this and additional works at: https://digitalcommons.unl.edu/usdaarsfacpub

Martin, K. L.; Hodgen, P. J.; Freeman, K. W.; Melchiori, Ricardo; Arnall, D. B.; Teal, R. K.; Mullen, R. W.; Desta, K.; Phillips, S. B.; Solie, J. B.; Stone, M. L.; Caviglia, Octavio; Solari, Fernando; Brianchini, Agustin; Francis, D. D.; Schepers, J. S.; Hatfield, J. L.; and Raun, W. R., "Plant-to-Plant Variability in Corn Production" (2005). Publications from USDA-ARS / UNL Faculty. 1344.

https://digitalcommons.unl.edu/usdaarsfacpub/1344

This Article is brought to you for free and open access by the U.S. Department of Agriculture: Agricultural Research Service, Lincoln, Nebraska at DigitalCommons@University of Nebraska - Lincoln. It has been accepted for inclusion in Publications from USDA-ARS / UNL Faculty by an authorized administrator of DigitalCommons@University of Nebraska - Lincoln. 


\section{Authors}

K. L. Martin, P. J. Hodgen, K. W. Freeman, Ricardo Melchiori, D. B. Arnall, R. K. Teal, R. W. Mullen, K. Desta, S. B. Phillips, J. B. Solie, M. L. Stone, Octavio Caviglia, Fernando Solari, Agustin Brianchini, D. D. Francis, J. S. Schepers, J. L. Hatfield, and W. R. Raun 


\title{
Plant-to-Plant Variability in Corn Production
}

\author{
K. L. Martin, P. J. Hodgen, K. W. Freeman, Ricardo Melchiori, D. B. Arnall, R. K. Teal, R. W. Mullen, \\ K. Desta, S. B. Phillips, J. B. Solie, M. L. Stone, Octavio Caviglia, Fernando Solari, Agustin Bianchini, \\ D. D. Francis, J. S. Schepers, J. L. Hatfield, and W. R. Raun*
}

\begin{abstract}
Corn (Zea mays $L_{\text {.) }}$ grain yields are known to vary from plant to plant, but the extent of this variability across a range of environments has not been evaluated. This study was initiated to evaluate by-plant corn grain yield variability over a range of production environments and to establish the relationships among mean grain yield, standard deviation, coefficient of variation, and yield range. A total of fortysix 8- to 30-m corn transects were harvested by plant in Argentina, Mexico, Iowa, Nebraska, Ohio, Virginia, and Oklahoma from 2002 to 2004. By-plant corn grain yields were determined, and the average individual plant yields were calculated. Over all sites in all countries and states, plant-to-plant variation in corn grain yield averaged 2765 $\mathrm{kg} \mathrm{ha}^{-1}$ (44.1 bu $\left.\mathrm{ac}^{-1}\right)$. At the sites with the highest average corn grain yield (11 478 and $14383 \mathrm{~kg} \mathrm{ha}^{-1}$, Parana Argentina, and Phillips, $\mathrm{NE}$ ), average plant-to-plant variation in yield was $4211 \mathrm{~kg} \mathrm{ha}^{-1}(67 \mathrm{bu}$ $\mathrm{ac}^{-1}$ ) and $2926 \mathrm{~kg} \mathrm{ha}^{-1}$ (47 bu $\mathrm{ac}^{-1}$ ), respectively. As average grain yields increased, so did the standard deviation of the yields obtained within each row. Furthermore, the yield range (maximum corn grain yield minus the minimum corn grain yield per row) was found to increase with increasing yield level. Regardless of yield level, plantto-plant variability in corn grain yield can be expected and averaged more than $2765 \mathrm{~kg} \mathrm{ha}^{-1}$ over sites and years. Averaging yield over distances $>0.5 \mathrm{~m}$ removed the extreme by-plant variability, and thus, the scale for treating other factors affecting yield should be less than $0.5 \mathrm{~m}$. Methods that homogenize corn plant stands and emergence may decrease plant-to-plant variation and could lead to increased grain yields.
\end{abstract}

$\mathrm{V}$ ARIABILITY IN PLANT stands is well documented. Nielsen (2001) studied plant-spacing variability (PSV) in 354 commercial fields of corn throughout Indiana and Ohio. This work showed that the standard deviation of plant spacing was $7.5 \mathrm{~cm}$ or less in only $16 \%$ of the fields. Sixty percent of the sampled fields exhibited standard deviations of plant spacing between 10 and $12.5 \mathrm{~cm}$. Plant-spacing standard deviations in $24 \%$ of the fields were $15 \mathrm{~cm}$ or greater (up to $30 \mathrm{~cm}$ ). Their results showed that for every $2.54 \mathrm{~cm}$ increase in the standard deviation in plant-to-plant spacing, $156 \mathrm{~kg} \mathrm{ha}^{-1}$ $\left(2.5 \mathrm{bu} \mathrm{ac}^{-1}\right)$ in grain yield was lost. The average standard deviation of plant spacing was $17.2 \mathrm{~cm}$ (6.8 in),

K.L. Martin, K.W. Freeman, D.B. Arnall, R.K. Teal, K. Desta, J.B. Solie, M.L. Stone, and W.R. Raun, Oklahoma State Univ., Stillwater, OK; P.J. Hodgen, Fernando Solari, D.D. Francis, and J.S. Schepers, USDA-ARS, Lincoln, NE; R. Melchiori and O. Caviglia, INTA, Parana, Argentina; R.W. Mullen, The Ohio State Univ., Columbus, OH; S.B. Phillips, Virginia Polytechnic Inst., Blacksburg, VA; Agustin Bianchini, AAPRESID, Rosario, Argentina; and J. Hatfield, USDAARS, Ames, IA. Received 3 May 2005. *Corresponding author (wrr@ mail.pss.okstate.edu).

Published in Agron. J. 97:1603-1611 (2005).

Corn

doi:10.2134/agronj2005.0129

(c) American Society of Agronomy

677 S. Segoe Rd., Madison, WI 53711 USA resulting in an estimated $1066 \mathrm{~kg} \mathrm{ha}^{-1}\left(17 \mathrm{bu} \mathrm{ac}^{-1}\right)$ yield loss over 354 commercial fields. Lauer and Rankin (2004) and Liu et al. (2004) had differing results, noting that PSV did not significantly alter grain yields in Wisconsin and Ontario, Canada, respectively. Nafziger et al. (1991) noted that uneven emergence of corn can occur when soils are dry at the time of planting and could lead to decreased grain yields. It is generally accepted that when adjacent plants differ by more than two leaf stages, the younger plant may not develop to its fullest potential. A two leaf stage difference can result from delayed emergence ranging from 5 to $10 \mathrm{~d}$, which can cause a $1 \%$ yield loss for each 1-d delay (Robert L. Nielsen, Purdue University, personal communication, 2004). Tollenaar and Wu (1999) found increased stress tolerance in corn when plant-to-plant variability was lower. In general, these statistics identify a twofold problem: first, the need to homogenize plant spacing and emergence and second, the need to recognize differences in yield potential that clearly exist by plant.

Some technologies in precision agriculture have been driven commercially. The most notable has been combine yield monitors. Depending on combine speed, header width, and the smoothing effect as grain moves through the combine, each sensed element represents more than $48 \mathrm{~m}^{2}$ (width of swath times the distance traveled in 2 to $4 \mathrm{~s}$ ). However, Lengnick (1997), Solie et al. (1999), and Raun et al. (1998) found significant soil variability at distances less than $30 \mathrm{~m}$ apart, and in many cases, less than $1 \mathrm{~m}$. Furthermore, large differences in measured yield have been reported on a small scale $\left(<0.4 \mathrm{~m}^{2}\right)$ for winter wheat (Triticum aestivum $\mathrm{L}$.) (Raun et al., 2002) and by plant in corn (Raun et al., 2005). For corn, the expressed spatial variability was greatest at the V6 growth stage (Ritchie et al., 1996). This peak in the within-row variability was thought to occur at the same growth stage where treating the variability would have the greatest impact (Raun et al., 2005). Maddonni and Otegui (2004) reported that the greatest difference in estimated shoot biomass between plant types occurred between V7 and V13 (Ritchie et al., 1996) and remained constant from V13 onward. Vega and Sadras (2003) found a strong inequality in reproductive output within high populations of corn, indicating an apparent breakage of reproductive allometry.

Varvel et al. (1997) noted that when sufficiency indices (determined with a SPAD meter) were lower than $90 \%$ at V8, maximum yields were not achieved with in-season $\mathrm{N}$ fertilizer applications because early-season available $\mathrm{N}$ was below that needed for optimum growth

Abbreviations: CV, coefficient of variation; NDVI, Normalized Difference Vegetative Index $=\left(\rho_{\mathrm{NIR}}-\rho_{\mathrm{Red}}\right) /\left(\rho_{\mathrm{NIR}}+\rho_{\mathrm{Red}}\right)$; PSV, plantspacing variability. 
and yield potentials had already been reduced. Therefore, if added $\mathrm{N}$ was needed, making the decision to apply should likely take place at or before V8.

Fundamental field element size is the area where maximum relatedness exists between adjacent elements. Treatment at scales larger than the fundamental field element size compromises the effectiveness since independent variation of nutrient levels exists within a single treatment level. Treatment at scales less than the fundamental field element size is pointless, as nutrient levels within this scale are related. When $\mathrm{N}$ decisions are at $1-\mathrm{m}^{2}$ resolution, the variability present can be detected (e.g., Normalized Difference Vegetative Index, or NDVI) and treated accordingly with foliar N (Solie et al., 1996; Stone et al., 1996), thus increasing $\mathrm{N}$ use efficiency. Taylor et al. (1999) reported that smaller plot sizes employed in variety trials reduced the variability encountered in estimating the mean yield. This was consistent with the resolution where detectable differences in soil test parameters exist that should be treated independently.

Porter et al. (1998) observed that temporal yield variability was approximately three times greater for soybean [Glycine $\max (\mathrm{L}$.$) (Merr.)] and four times greater$ for corn than spatial variability among plots. They also reported that producers should not change management practices (as a function of yield maps) unless the differences were shown to be consistent over years. Mallarino et al. (1999) employed grid sampling and factor analysis to investigate the relationship between several site variables (soil tests, plant population, weed control, etc.) and corn grain yields in five producer fields. They reported that some of the variables collected were correlated with grain yields, but that the relationships changed between fields. When collecting corn grain yield data from twenty-four 4.6- by 3.0-m subplots within a larger farmer field, Schmidt et al. (2002) showed that yields ranged from 4.7 to $9.5 \mathrm{Mg} \mathrm{ha}^{-1}$. It is important to note that this large range in yield was from plots that did not receive any fertilizer $\mathrm{N}$. They also noted that variable $\mathrm{N}$ application is needed to achieve maximum grain yield and improved $\mathrm{N}$ management over different locations in the same field. Sadler et al. (1998) noted that Coastal Plain soils required study at finer resolutions than the $>100$-m grids commonly used in precision farming.

The objectives of this study were (i) to evaluate byplant corn grain yield variability over a range of production environments; (ii) to determine the relationships among mean grain yield, standard deviation of yield, coefficient of variation $(\mathrm{CV})$ of yield, and yield range; and (iii) to evaluate the relationship between NDVI and corn grain yields.

\section{MATERIALS AND METHODS}

In accordance with the countries and states where data were collected for this paper, the following production statistics are provided. In 2003, world corn grain production averaged 4.5 $\mathrm{Mg} \mathrm{ha}^{-1}$, coming from 142 million ha. Average corn grain yields in the USA, Argentina, and Mexico were 8.9, 6.4, and $2.5 \mathrm{Mg} \mathrm{ha}^{-1}$ from $28,2.3$, and 7.8 million ha, respectively (http://faostat.fao.org; verified 19 Aug. 2005). In Iowa, Ne- braska, Ohio, Virginia, and Oklahoma, average corn grain yield for 2003 was 9.8, 9.2, 8.7, 7.2, and 7.8 $\mathrm{Mg} \mathrm{ha}^{-1}$ from 4.8, $3.1,1.2,0.13$, and 0.08 million ha, respectively (www.usda.gov/ nass/nasshome.htm; verified 19 Aug. 2005).

By-plant harvested corn grain yields from 13 different sites in Argentina, Mexico, Iowa, Nebraska, Ohio, Virginia, and Oklahoma were evaluated to determine relationships among by-plant and averaged yield and ranges, standard deviations, and coefficients of variation of yields. At each location, corn rows (transects) ranging from 8 to $30 \mathrm{~m}$ in length were selected for by-plant harvesting. At most of the sites, individual plants were marked at or before the V8 growth stage to ensure detection of barren and/or lost plants at harvest (60-85 d later depending on the maturity). At the same time that plants were tagged, a tape measure was extended the length of the row, and cumulative distances were recorded for each plant.

At most sites, based on the row spacing used at each location, the area occupied by each plant was calculated. This was done by assuming that each plant occupied half the distance to and from its nearest neighbor (Eq. [1]):

$$
A_{i}=\left[\frac{d_{i}-d_{i-1}}{2}+\frac{d_{i+1}-d_{i}}{2}\right] R
$$

where $A_{i}$ is the area occupied by the $i$ th plant; $d_{i-1}, d_{i}$, and $d_{i+1}$ are the distances to the $i-1, i$, and $i+1$ plants; and $R$ is the row spacing.

Each ear was harvested individually from each plant and the weight recorded. When more than one ear per plant was present, total weight was recorded on a by-plant basis. At those sites where actual distances between plants were not recorded, an average distance occupied per plant was determined based on row spacing and total transect or row distance and number of plants harvested per row. Once removed from the stalk, ears were dried at $66^{\circ} \mathrm{C}$ for $48 \mathrm{~h}$ and weighed before and after shelling. The dry grain weight taken from the shelled corn was the final weight used for yield determination. The locations sampled, number of transects at each site, planting date, harvest date, row spacing, plant population, hybrid, and maturity are reported in Table 1. Location, soil series, texture, and transect length are included in Table 2. At some of the sites, NDVI data were collected at the V8 growth stage, directly over the corn row using a shaft encoding GreenSeeker sensor placed $76 \mathrm{~cm}$ above the corn canopy and that was capable of recording NDVI readings with computed distance every $0.5 \mathrm{~cm}$. Sensor NDVI readings were then averaged for consecutive four-plant clusters. Corn ears from these fourplant clusters were harvested and shelled to evaluate the relationship between NDVI readings at V8 and final grain yield.

Statistical analysis included regression of average grain yield per transect on the standard deviation, $\mathrm{CV}$, and yield range of by-plant grain yield over all locations using SAS (SAS Inst., 2002). The areas where by-plant harvest data were collected were representative of a range of corn production environments around the world. The previous crop and tillage practice employed at each site are reported in Table 2.

\section{RESULTS}

Average transect corn grain yield plotted against standard deviation, $\mathrm{CV}$, and yield range over all locations is illustrated in Fig. 1, 2, and 3, respectively. Prediction equations reported and plotted on Fig. 1-3 do not exceed the limits of the collected data. The standard deviation of by-plant corn grain yield increased with increasing yield level up to $13000 \mathrm{~kg} \mathrm{ha}^{-1}$ (Fig. 1). This is consistent with several sources reporting that the stan- 
Table 1. Location, transect, year, planting date, harvest date, row spacing, plant population, and corn hybrids where corn grain yields were evaluated by plant from 2002 to 2004 from transects ranging from 8 to $30 \mathrm{~m}$ of row, USA, Argentina, and Mexico.

\begin{tabular}{|c|c|c|c|c|c|c|c|c|}
\hline Location & Transect & Year & Planting date & Harvest date & $\begin{array}{c}\text { Row } \\
\text { spacing }\end{array}$ & $\begin{array}{c}\text { Plant } \\
\text { population }\end{array}$ & Maturity & Hybrid \\
\hline & & & & & cm & plants ha ${ }^{-1}$ & d & \\
\hline El Batan, Mexico & 1 & 2002 & 24 July 2002 & 4 Dec. 2002 & 76 & 62656 & 125 & CMS-939083 \\
\hline El Batan, Mexico & 1 & 2002 & 24 July 2002 & 4 Dec. 2002 & 76 & 62656 & 125 & CMS-939083 \\
\hline El Batan, Mexico & 2 & 2002 & 24 July 2002 & 4 Dec. 2002 & 76 & 62656 & 125 & CMS-939083 \\
\hline El Batan, Mexico & 3 & 2002 & 24 July 2002 & 4 Dec. 2002 & 76 & 62656 & 125 & CMS-939083 \\
\hline Lake Carl Blackwell, OK & 3 & 2003 & 8 Apr. 2003 & 11 Aug. 2003 & 76 & 32918 & 104 & Pioneert \\
\hline Lake Carl Blackwell, OK & 4 & 2003 & 8 Apr. 2003 & 11 Aug. 2003 & 76 & 30056 & 104 & Pioneer $\dagger$ \\
\hline EFAW, OK & 2 & 2003 & 31 Mar. 2003 & 5 Aug. 2003 & 76 & 53689 & 111 & Asgrow $\dagger$ \\
\hline EFAW, OK & 1 & 2003 & 31 Mar. 2003 & 5 Aug. 2003 & 76 & 53043 & 111 & Asgrow $\dagger$ \\
\hline EFAW, OK & 3 & 2003 & 31 Mar. 2003 & 5 Aug. 2003 & 76 & 49403 & 111 & Asgrow $\dagger$ \\
\hline EFAW, OK & 4 & 2003 & 31 Mar. 2003 & 5 Aug. 2003 & 76 & 50412 & 111 & Asgrow $\dagger$ \\
\hline Lake Carl Blackwell, OK & $\mathbf{1}$ & 2004 & 27 Apr. 2004 & 2 Aug. 2004 & 76 & 60735 & 108 & Pioneer Bt $\dagger$ \\
\hline Lake Carl Blackwell, OK & 2 & 2004 & 3 Apr. 2004 & 2 Aug. 2004 & 76 & 63072 & 108 & Pioneer Bt $\dagger$ \\
\hline Lake Carl Blackwell, OK & 3 & 2004 & 27 Apr. 2004 & 2 Aug. 2004 & 76 & 37287 & 108 & Pioneer Bt $\dagger$ \\
\hline Lake Carl Blackwell, OK & 4 & 2004 & 3 Apr. 2004 & 2 Aug. 2004 & 76 & 35496 & 108 & Pioneer Bt $\dagger$ \\
\hline Lake Carl Blackwell, OK & 5 & 2004 & 3 Apr. 2004 & 2 Aug. 2004 & 76 & 57243 & 108 & Pioneer Bt ${ }^{\dagger}$ \\
\hline Lake Carl Blackwell, OK & 6 & 2004 & 27 Ápr. 2004 & 2 Aug. 2004 & 76 & 57572 & 108 & Pioneer Bt ${ }^{\dagger}$ \\
\hline Hennessey, OK & 2 & 2004 & 27 Apr. 2004 & 13 Sept. 2004 & 76 & 35511 & 113 & Pioneer Bt $\dagger$ \\
\hline Hennessey, OK & 1 & 2004 & 27 Apr. 2004 & 13 Sept. 2004 & 76 & 36166 & 113 & Pioneer Bt $\dagger$ \\
\hline EFAW, OK & 1 & 2004 & 7 Apr. 2004 & 27 Aug. 2004 & 76 & 65846 & 113 & Pioneer Bt $\dagger$ \\
\hline EFAW, OK & 1 & 2004 & 7 Apr. 2004 & 25 Aug. 2004 & 76 & 65429 & 108 & Pioneer Bt $\dagger$ \\
\hline EFAW, OK & 2 & 2004 & 7 Apr. 2004 & 25 Aug. 2004 & 76 & 70942 & 108 & Pioneer Bt $\dagger$ \\
\hline EFAW, OK & 3 & 2004 & 7 Apr. 2004 & 25 Aug. 2004 & 76 & 36259 & 108 & Pioneer Bt $\dagger$ \\
\hline EFAW, OK & 4 & 2004 & 7 Apr. 2004 & 25 Aug. 2004 & 76 & 37799 & 113 & Pioneer Bt $\dagger$ \\
\hline Perkins, OK & 1 & 2004 & 2 Apr. 2004 & 27 Aug. 2004 & 76 & 48410 & 108 & Pioneer Bt $\dagger$ \\
\hline Ames, IA & east & 2004 & 10 May 2004 & 24 Sept. 2004 & 76 & 55808 & 105 & Pioneer 35P17 \\
\hline Ames, IA & west & 2004 & 10 May 2004 & 24 Sept. 2004 & 76 & 68018 & 105 & Pioneer 35P17 \\
\hline Shelton, NE & 1 & 2004 & 7 May 2004 & 13 Oct. 2004 & 91 & 72778 & 118 & Pioneer 31N27 \\
\hline Shelton, NE & 2 & 2004 & 7 May 2004 & 13 Oct. 2004 & 91 & 71590 & 118 & Pioneer 31N27 \\
\hline Wooster, ОН & 1 & 2004 & 7 May 2004 & 25 Oct. 2004 & 76 & 70395 & 111 & Bird B64 \\
\hline Parana, Argentina & 1-4-5 & 2003 & 16 Sept. 2003 & 20 Feb. 2003 & 70 & 90578 & 120 & Dekalb 682 MG \\
\hline Parana, Argentina & 12-13-14 & 2003 & 16 Sept. 2003 & 20 Feb. 2003 & 70 & 88786 & 120 & Dekalb 682 MG \\
\hline Parana, Argentina & $16-17-20$ & 2003 & 16 Sept. 2003 & 20 Feb. 2003 & 70 & 89795 & 120 & Dekalb 682 MG \\
\hline Parana, Argentina & 21-22-25 & 2003 & 16 Sept. 2003 & 20 Feb. 2003 & 70 & 94978 & 120 & Dekalb 682 MG \\
\hline Parana, Argentina & 31-33-35 & 2003 & 16 Sept. 2003 & 20 Feb. 2003 & 70 & 93185 & 120 & Dekalb 682 MG \\
\hline Parana, Argentina & 41-42-43 & 2003 & 16 Sept. 2003 & 20 Feb. 2003 & 70 & 90015 & 120 & Dekalb 682 MG \\
\hline Parana, Argentina & $46-49-50$ & 2003 & 16 Sept. 2003 & 20 Feb. 2003 & 70 & 92378 & 120 & Dekalb 682 MG \\
\hline Parana, Argentina & $56-57-60$ & 2003 & 16 Sept. 2003 & 20 Feb. 2003 & 70 & 93595 & 120 & Dekalb 682 MG \\
\hline Painter, VA & $\mathbf{1 , 5 , 9}$ & 2003 & 5 May 2003 & 17 Sept. 2003 & 76 & 69136 & 120 & Pioneer 32R25 \\
\hline Painter, VA & $2,6,10$ & 2003 & 5 May 2003 & 17 Sept. 2003 & 76 & 69136 & 120 & Pioneer 32R25 \\
\hline Painter, VA & $3,7,11$ & 2003 & 5 May 2003 & 17 Sept. 2003 & 76 & 69136 & 120 & Pioneer 32R25 \\
\hline Painter, VA & 4,8 & 2003 & 5 Мау 2003 & 17 Sept. 2003 & 76 & 69136 & 120 & Pioneer 32R25 \\
\hline Phillips, NE & 1-2 & 2004 & 1 May 2004 & 8 Nov. 2004 & 76 & 66810 & 116 & Pioneer 32T78 \\
\hline Phillips, NE & 3-4 & 2004 & 1 May 2004 & 8 Nov. 2004 & 76 & 64655 & 116 & Pioneer 32T78 \\
\hline Phillips, NE & $5-6$ & 2004 & 1 May 2004 & 8 Nov. 2004 & 76 & 66810 & 116 & Pioneer 32T78 \\
\hline Phillips, NE & $7-8$ & 2004 & 1 May 2004 & 8 Nov. 2004 & 76 & 72198 & 116 & Pioneer 32T78 \\
\hline Phillips, NE & 9-10 & 2004 & 1 May 2004 & 8 Nov. 2004 & 76 & 64655 & 116 & Pioneer 32T78 \\
\hline
\end{tabular}

$\dagger$ Experimental hybrid donated by Pioneer and Asgrow; actual number not made available.

dard deviation of yields increases with increasing yield level (Taylor et al., 1999; Dobermann et al., 2003). The $\mathrm{CV}$ of by-plant yields was negatively correlated with mean grain yield across the range of experiments studied (Fig. 2). The test for the slope (negative) being different from zero was highly significant $(P>|t|, 0.0007)$. Even

Table 2. Soil series and texture from location transects ranging from 8 to $30 \mathrm{~m}$ of row, USA, Argentina, and Mexico.

\begin{tabular}{|c|c|c|c|c|c|c|}
\hline Location & Site-year & Soil series & $\begin{array}{l}\text { Previous } \\
\text { crop }\end{array}$ & Tillage & Soil texture & $\begin{array}{c}\text { Meters per } \\
\text { transect }\end{array}$ \\
\hline & & & & & & $\mathbf{m}$ \\
\hline EI Batan, Mexico & 2002 & Fluventic Hapludoll & wheat & conventional & silt loam & 27 \\
\hline Lake Carl Blackwell, OK & 2003 & Port-oscar & corn & conventional & silt loam & 30 \\
\hline EFAW, OK & 2003 & Easpur & wheat & conventional & loam & 30 \\
\hline Lake Carl Blackwell, OK & 2004 & Port-oscar & corn & conventional & silt loam & 30 \\
\hline Hennessey, OK & 2004 & Shellabarger & corn & conventional & sandy loam & 30 \\
\hline EFAW, OK & 2004 & Easpur & corn & conventional & loam & 30 \\
\hline EFAW, OK & 2004 & Easpur & corn & conventional & loam & 13.5 \\
\hline Perkins, OK & 2004 & Teller & corn & conventional & sandy loam & 10 \\
\hline Ames, IA & 2004 & Clarion & corn & conventional & loam & $23,19 \dagger$ \\
\hline Shelton, NE & 2004 & Hord & corn & conventional & silt loam & $15,19 \dagger$ \\
\hline Wooster, OH & 2004 & Canfield & soybean & no-till & silt loam & 8.1 \\
\hline Parana, Argentina & 2003 & Tezanos Pinto & soybean & no-till & silt loam & $10.5 \div$ \\
\hline Painter, VA & 2003 & Bojac & potato & conventional & sandy loam & 9.1 \\
\hline Phillips, NE & 2004 & Ully & corn & conventional & silt loam & $12.2 \S$ \\
\hline
\end{tabular}

$\dagger$ Transect length was different for each row at these sites.

† Designates locations where three rows, side by side, were combined to form a larger transect.

$\S$ Designates locations where two rows, side by side, were combined to form a larger transect. 


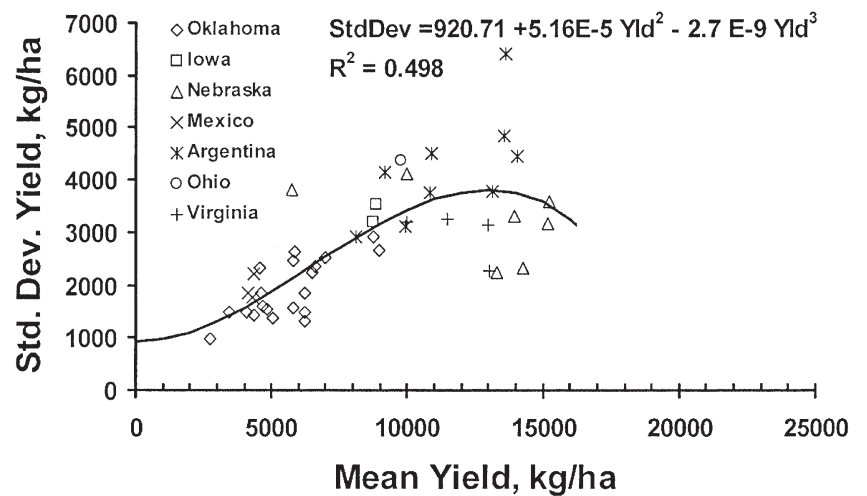

Fig. 1. Average corn grain yield plotted against the standard deviation from by-plant yield over 46 transects in Argentina, Mexico, Iowa, Nebraska, Ohio, Virginia, and Oklahoma.

though CVs were lower for the higher-yielding sites, the actual plant-to-plant variation in grain yield $(\mathrm{kg}$ $\mathrm{ha}^{-1}$ ) was greater when compared with sites with lower average yields. The yield range (maximum yield observed in each transect minus the minimum yield observed) increased with average corn grain yields (Fig. 3).

Average grain yield across all regions ranged from 4268 to $14383 \mathrm{~kg} \mathrm{ha}^{-1}$, with an average of $8495 \mathrm{~kg} \mathrm{ha}^{-1}$ $\left(135 \mathrm{bu} \mathrm{ac}^{-1}\right)$, close to the U.S. average and above that for Argentina and Mexico (Table 3). The average differences in measured yield plant to plant ranged from 1724 to $4367 \mathrm{~kg} \mathrm{ha}^{-1}$ (excluding barren plants) and averaged $2765 \mathrm{~kg} \mathrm{ha}^{-1}$ (44.1 bu ac ${ }^{-1}$ ) (Table 3). At those sites where the average yields were the highest (Phillips, NE, and Argentina), the standard deviations about the yield mean were $2926 \mathrm{~kg} \mathrm{ha}^{-1}\left(47 \mathrm{bu} \mathrm{ac}^{-1}\right)$ and $4211 \mathrm{~kg} \mathrm{ha}^{-1}$ (67 bu ac ${ }^{-1}$ ), respectively. Although a trend for decreased CVs at the higher yield levels was observed (Fig. 2), the average plant-to-plant yield differences that would be encountered at both these high-yielding sites exceeded the average over all locations where yields were much lower.

\section{DISCUSSION}

The sites reported in this paper were planted and treated using normal practices in each region. No steps were taken to minimize cultural, nutrient, or environmental factors that would keep the corn hybrids from

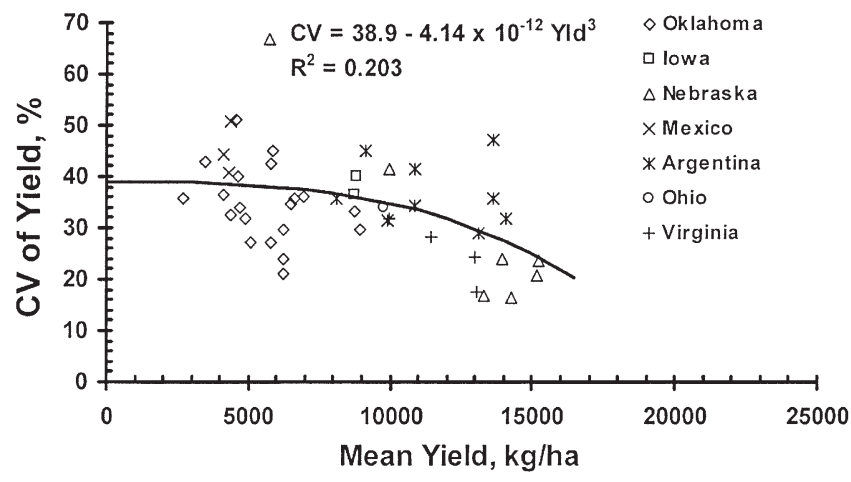

Fig. 2. Average corn grain yield plotted against the coefficient of variation from by-plant yields over 46 transects in Argentina, Mexico, Iowa, Nebraska, Ohio, Virginia, and Oklahoma.

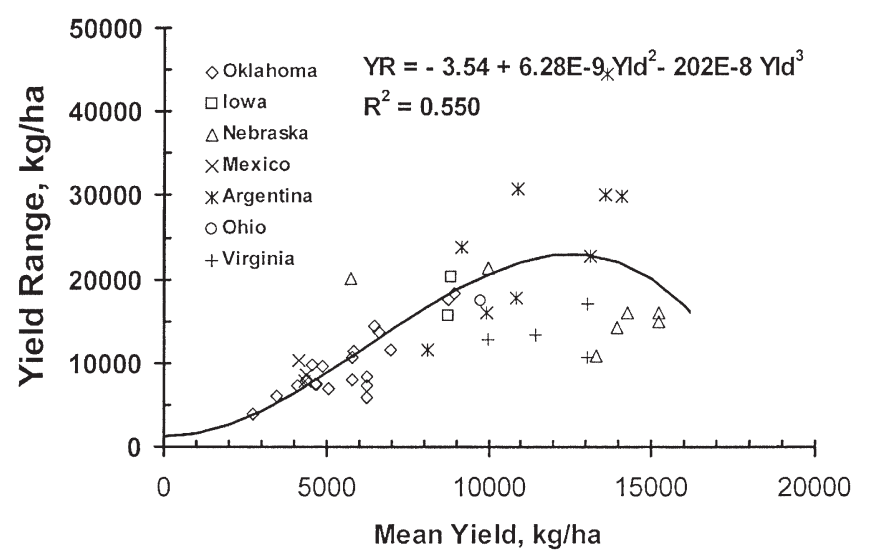

Fig. 3. Average corn grain yield plotted against the by-plant yield range (maximum minus minimum yield) in 46 transects ranging from 10.5 to $30 \mathrm{~m}$ in length in Argentina, Mexico, Iowa, Nebraska, Ohio, Virginia, and Oklahoma.

achieving their genetic yield potential. To achieve the theoretical maximum genetic yield potential, stands must be optimum, plant spacing must be exact, seed must be planted at ideal and uniform depth, germination should be $100 \%$, all nutrients must be nonlimiting, soil types and physical properties must be uniform and ideal for the cultivar, and moisture, temperature, and all other environmental factors must be ideal during the entire growing season. All plants must emerge within $1 \mathrm{~d}$. All plants must set at least one ear of corn, and the ear must completely fill. Under these conditions, the range of yield and standard deviation of yield should theoretically approach zero.

\section{Causes for the Large Differences in By-Plant Corn Grain Yields}

There are many variables that likely contributed to the extensive variability in by-plant corn grain yield seen at all sites included in this study. Delayed and uneven emergence can be caused by variable depth of planting, wheel compaction, location of the seed within the furrow, surface crusting, random soil clods, soil texture differences, variable distance between seeds, seed germination, variable soil compaction around the seed, insect damage, moisture availability, variable surface residue, variable seed furrow closure, and/or many other factors that influence nonuniformity of plants. In light of the many factors known to influence plant stands, within-row variability in corn grain yield should be expected, and that was present in the trials evaluated here. In all trials, common hybrids were employed for each respective region. Each row was inspected early in the season (excluding the Phillips, NE location) for volunteer corn, and these plants were removed. The presence of volunteer corn plants was scarce, especially in Virginia, Argentina, Mexico, Ohio, and some sites in Oklahoma where corn was not the previous crop (Table 2).

The range of average yields (2700-16100 $\mathrm{kg} \mathrm{ha}^{-1}$ ) included in this study was representative of a wide array of production environments (Fig. 1-3). Some of these sites were irrigated while others relied on natural precipitation. One of the sources of plant-to-plant variability 
Table 3. Minimum, maximum, mean, standard deviation, maximum/minimum, and coefficient of variation (CV) for by-plant corn grain yields from 46 transects in Argentina, Mexico, Iowa, Nebraska, Ohio, Virginia, and Oklahoma, 2002-2004.

\begin{tabular}{|c|c|c|c|c|c|c|c|c|}
\hline Location & Years & Transects & Min. yield & Max. yield & Mean yield & SD & Max./min. & $\mathbf{C V}$ \\
\hline & & & & - kg & & - & & $\%$ \\
\hline El Batan, Mexico & 2002 & 3 & 606 & 9440 & 4268 & 1935 & 22.4 & 45.3 \\
\hline OK, <6000 kg ha ${ }^{-1}$ & 2003-2004 & 12 & 1128 & 9169 & 4652 & 1724 & 10.0 & 37.2 \\
\hline$O K,>6000 \mathrm{~kg} \mathrm{ha}^{-1}$ & 2003-2004 & 8 & 1947 & 14120 & 7050 & 2167 & 11.6 & 30.5 \\
\hline Ames, IA, Shelton, NE & 2004 & 4 & 1872 & 21173 & 8320 & 3660 & 14.1 & 46.0 \\
\hline Wooster, OH & 2004 & 1 & 2066 & 19458 & 9759 & 4367 & 9.4 & 50.2 \\
\hline Parana, Argentina & 2003 & 9 & 2806 & 28058 & 11478 & 4211 & 15.0 & 36.8 \\
\hline Painter, VA & 2003 & 4 & 4753 & 24552 & 11943 & 3171 & 5.2 & 26.7 \\
\hline Phillips, NE & 2004 & 5 & 7098 & 21492 & 14383 & 2926 & 3.2 & 20.3 \\
\hline All sites & 2002-2004 & 46 & 2752 & 17281 & 8495 & 2765 & 11.1 & 34.3 \\
\hline
\end{tabular}

could be competition for soil moisture, especially in dryland fields. However, this would be an unlikely source of plant-to-plant variability at the higher yield levels where moisture was not limiting $\left(>13000 \mathrm{~kg} \mathrm{ha}^{-1}\right)$, unless soil texture differences were expected at the byplant level. Similarly, the extensive plant to-plant differences in grain yield within 8 to $30 \mathrm{~m}$ of row were unlikely due to plant-to-plant differences in early-season $\mathrm{N}$ availability.

Maddonni and Otegui (2004) noted that increased interplant competition in corn hybrids enhanced the appearance of plants with different competitive abilities. Thus at higher populations, plant-to-plant variation can also be expected. They noted that the onset of interplant competition started very early during the life cycle and that differences in estimated plant biomass between stand densities were detected as early as V6. Furthermore, they reported that plant population and row-spacing treatments alone did not modify the onset of the hierarchical growth among plants. The same causes for delayed and uneven emergence discussed earlier in this section would likely be expressed later in the life cycle with variable plant growth.

\section{Expression of Variability}

Seed suppliers do not normally publish genetic yield potential data (Fig. 1-3). However, the National Corn Growers Association Corn Yield Contest results (www. ncga.com/02profits/CYC/winners/winners.html; verified 19 Aug. 2005) can serve as a surrogate for these data. To achieve maximum yields, contest participants attempt to manage all factors under their control to minimize reduction in corn yield from the cultivars' genetic yield potential. The highest first-place yields for all classes from 2002, 2003, and 2004 ranged from 19000 to 22000 $\mathrm{kg} \mathrm{ha}^{-1}$.

Nonlinear equations were fitted to the data using Table Curve 2D (Systat Software, 2000). The equations with the highest $R^{2}$, which conformed to the upper and lower boundary conditions, were selected. In all cases, a partial cubic polynomial model met these requirements, and that was fit using a zero intercept. Examination of Fig. 1 through 3 yielded the following additional observations on the relationship of average corn yield to $\mathrm{CV}$, range, and standard deviation. The range and standard deviation curves peaked near $13000 \mathrm{~kg} \mathrm{ha}^{-1}$. The corn byplant yield $\mathrm{CV}$ was nearly constant for yields under $10000 \mathrm{~kg} \mathrm{ha}^{-1}$ and declined moderately to $15000 \mathrm{~kg} \mathrm{ha}^{-1}$.
Average field scale corn yields in all areas reported in this paper were generally much lower than $15000 \mathrm{~kg} \mathrm{ha}^{-1}$. The by-plant corn yield variability was large within the yield ranges achieved by producers, as indicated by the state and country averages cited previously. Because the overall plant-to-plant variation in yield was found to be $2765 \mathrm{~kg} \mathrm{ha}^{-1}$ (44.1 bu ac${ }^{-1}$ ) (Table 3), it will likely be important to recognize and treat these differences. If it is feasible to recognize $2765 \mathrm{~kg} \mathrm{ha}^{-1}$ plant-to-plant yield differences when average yields are $4300 \mathrm{~kg} \mathrm{ha}^{-1}$, it should be feasible to detect them when average yields are $14000 \mathrm{~kg} \mathrm{ha}^{-1}$.

\section{Errors Associated with By-Plant Yield}

Using the average plant yield of $120 \mathrm{~g}$ (dry shelled weight) over all trials included in this study and randomly applying all the errors included in the estimate (scale precision of $0.05 \mathrm{~g}$, by-plant tape measure precision of $1.0 \mathrm{~cm}$, and row spacing error of $1 \mathrm{~cm}$ ), the yield estimate was $645 \mathrm{~g} \mathrm{~m}^{-2}$ or $6453 \mathrm{~kg} \mathrm{ha}^{-1}$, which would be off by $5.8 \%$ when compared with the true value with no errors $\left(6073 \mathrm{~kg} \mathrm{ha}^{-1}\right)$ using a $26-\mathrm{cm}$ distance between plants and a $76-\mathrm{cm}$ row spacing. Similarly, a $5.2 \%$ error was found when estimating yield from larger plots (harvesting two rows, $13.6 \mathrm{~m}$ in length) using a field plot combine [plot weight of $10.5 \pm 0.2 \mathrm{~kg}$ (on-board scale precision) and a row distance of $13.6 \pm 0.2 \mathrm{~m}$, row spacing of $76 \pm 1 \mathrm{~cm}]$. This suggests that estimates of by-plant yields are no more problematic than small plot work using all the respective errors.

Work by Taylor et al. (1999) showed that standard deviations about yield means increased as mean yields increased in 220 fertilizer, weed management, and tillage trials, and that was similarly encountered in the trials reported here. Also, Taylor et al. (1999) reported a decrease in yield $\mathrm{CV}$ when mean yields increased. However, unlike the work of Taylor et al. (1999), which focused on plot data, we report on the standard deviations associated with by-plant differences in measured grain yield.

The average maximum/minimum range observed was $11 \times$ (46 transects ranging from 8 to $39 \mathrm{~m}$ of row) (Table 3). This came from experiments with an average yield of $8495 \mathrm{~kg} \mathrm{ha}^{-1}$, well above the world average of $4500 \mathrm{~kg} \mathrm{ha}^{-1}$ reported for corn grain yield in 2003 . Furthermore, the data collected at specific sites within each location (Argentina, Mexico, Iowa, Nebraska, Ohio, Virginia, and Oklahoma) had yields equal to or 

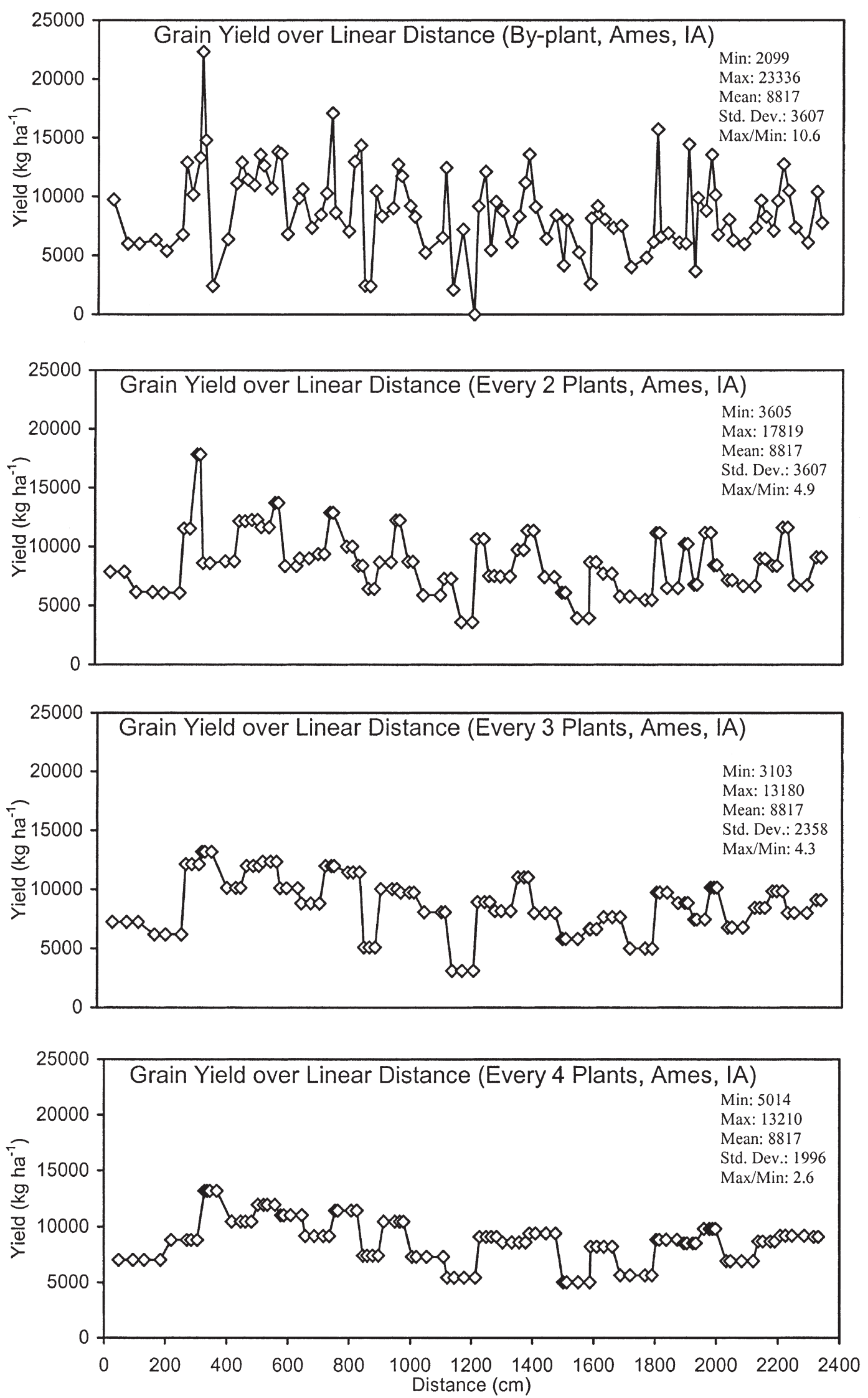

Fig. 4. Average corn grain yields plotted by plant, every two plants, every three plants, and every four plants, using measured distances between plants at Ames, IA in 2004. 

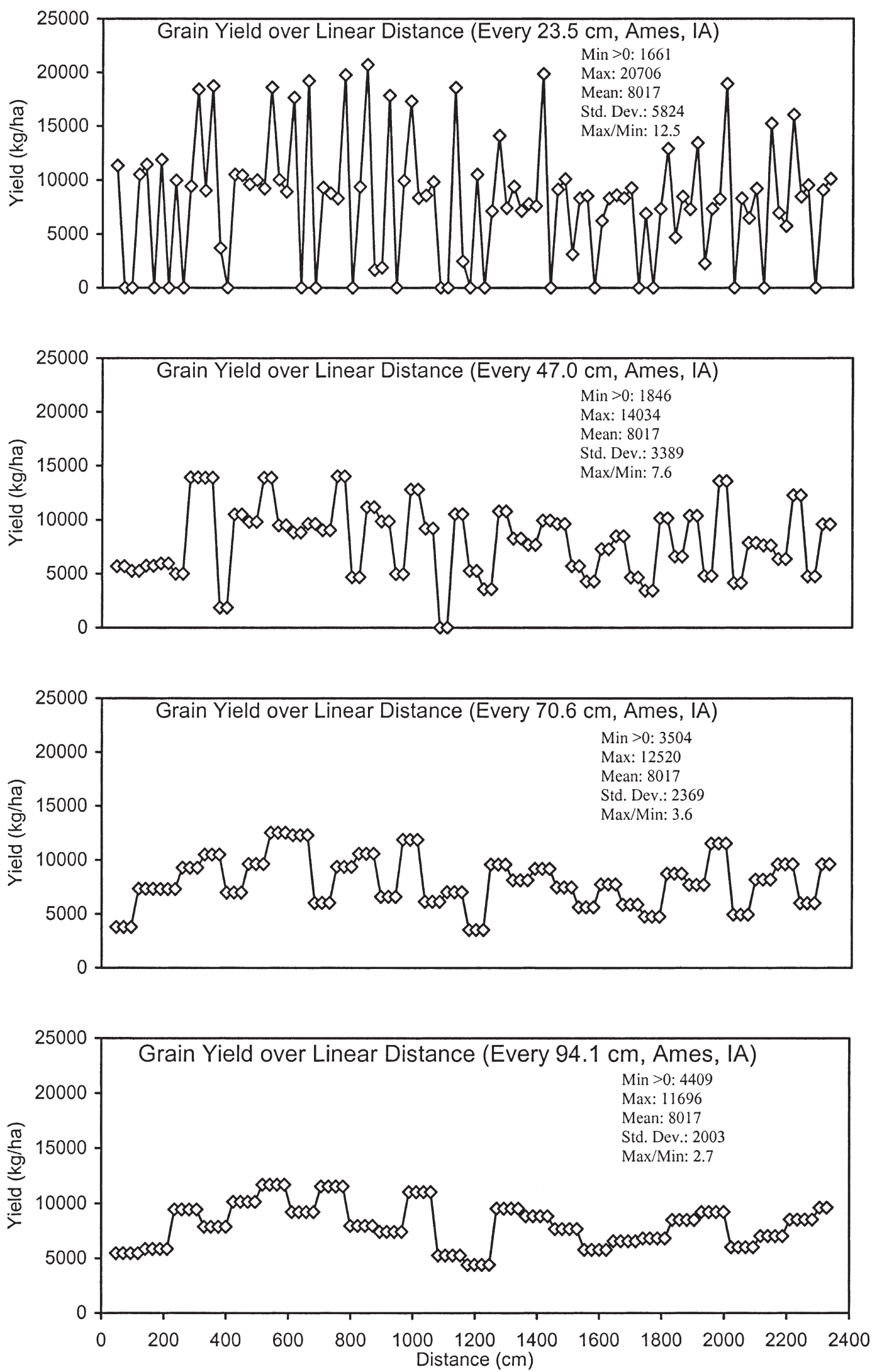

Fig. 5. Average corn grain yields computed using fixed distances of 23.5, 47.0, 70.6, and $94.1 \mathrm{~cm}$ at Ames, IA in 2004. 


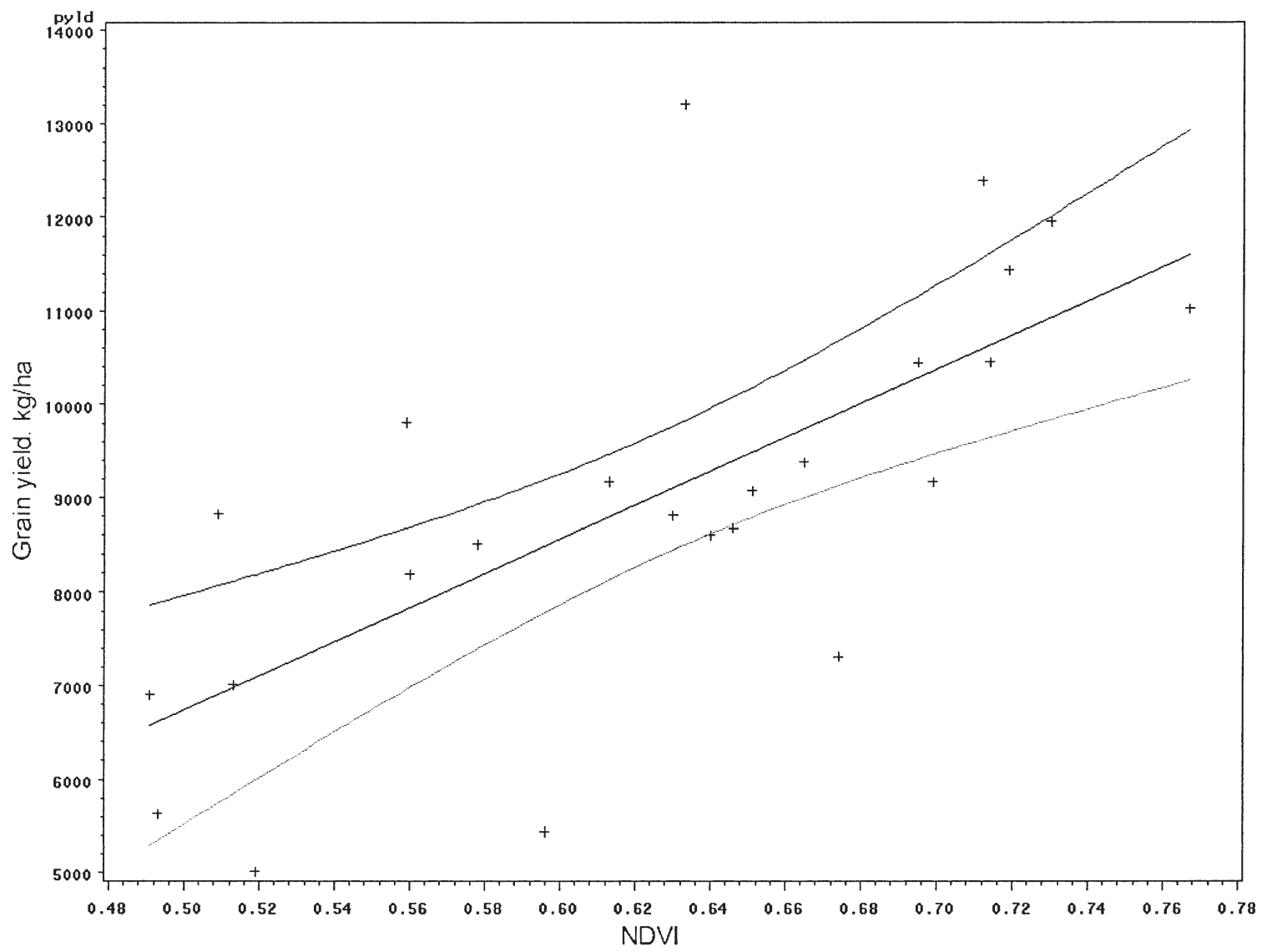

Yield $=-2348+18181($ NDVI)

$\mathrm{R}^{2}=0.49$

Yield Mean: 8817

Standard Deviation: 1565

Fig. 6. Normalized Difference Vegetative Index (NDVI) versus corn grain yield determined for every four plants using linear regression and associated $95 \%$ confidence intervals, east row at Ames, IA in 2004.

exceeding each specific region's average. Dobermann et al. (2003) reported corn grain yields from 4- by 4-m grids determined from yield monitor data from 1996

Table 4. Absolute value of the errors in estimating by-plant corn yield by averaging yield over a fixed distance along the row.

\begin{tabular}{|c|c|c|c|}
\hline Distance & Mean error & Maximum error & Minimum erro \\
\hline cm & \multicolumn{3}{|c|}{ Shelton, NE } \\
\hline 15.0 & 5254 & 19562 & o \\
\hline 30.0 & 4401 & 19562 & 65 \\
\hline 45.1 & 3877 & 14961 & 13 \\
\hline 60.1 & 3687 & 11249 & 12 \\
\hline $\begin{array}{l}75.1 \\
75.1\end{array}$ & 3906 & 17271 & 24 \\
\hline 90.1 & 3784 & 14170 & 3 \\
\hline \multirow[t]{2}{*}{1503} & 3569 & 1392 & 55 \\
\hline & \multicolumn{3}{|c|}{ Ames, IA } \\
\hline 23.5 & 5497 & 22336 & 83 \\
\hline 47 & 3588 & 17347 & 7 \\
\hline 70.5 & 3101 & 16191 & 14 \\
\hline 94 & 2937 & 15233 & 93 \\
\hline \multirow[t]{2}{*}{2352} & 2798 & 13519 & 7 \\
\hline & \multicolumn{3}{|c|}{ EFAW, OK } \\
\hline 20.1 & 3283 & 14634 & o \\
\hline 40.1 & 2538 & 8962 & 56 \\
\hline 60.2 & 2166 & 8227 & 76 \\
\hline 80.2 & 2023 & 9207 & 15 \\
\hline 100.3 & 2280 & 10030 & 15 \\
\hline 2989 & 2473 & 10569 & 10 \\
\hline
\end{tabular}

to 2001. In this work, the maximum/minimum yields observed in the entire field exceeded $20 \times$.

\section{Corn Grain Yields Averaged over Larger Scales}

If it were not possible to recognize each plant individually using sensors as has been published, it would be

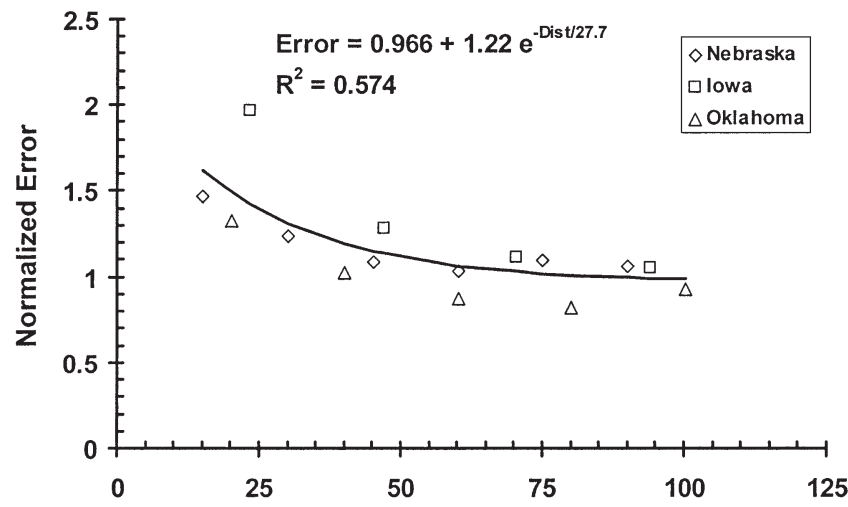

Distance Averaged Along Row, cm

Fig. 7. Effect of averaging plant yields over a specified distance along the row on the absolute error incurred when using the average corn yield for estimating the by-plant yield. Yields were normalized by the average yield along the entire row. 
considered important to evaluate the error in predicting by-plant yields when yields were averaged over different scales, either by more than one plant or by a fixed distance. To investigate this, by-plant grain yields were averaged over two, three, and four plants in $15 \mathrm{~m}$ of row from the Ames, IA location (Fig. 4). The largest differences in corn yield were discernable at the byplant level. However, 4.9, 4.3, and 2.6× differences were detected within $15 \mathrm{~m}$ of row when averaged over two, three, and four plants, respectively (Fig. 4). At this site, the average differences in yield (standard deviation) were $3607,2678,2358$, and $1996 \mathrm{~kg} \mathrm{ha}^{-1}$ when yields were averaged over one, two, three, and four plants. When averaged over every four plants, this scale resulted in average differences between four-plant clusters that exceeded $1900 \mathrm{~kg} \mathrm{ha}^{-1}\left(30 \mathrm{bu} \mathrm{ac}^{-1}\right)$. In addition, when evaluating every four-plant cluster in $15 \mathrm{~m}$ of row, the range in yields was 5014 to $13210 \mathrm{~kg} \mathrm{ha}^{-1}$ (difference of $8196 \mathrm{~kg} \mathrm{ha}^{-1}$ or $131 \mathrm{bu} \mathrm{ac}^{-1}$ ).

For the data in Fig. 4, grain yields were determined based on actual measured distances between plants and the area calculated from Eq. [1], which resulted in 10.6× differences in corn grain yield over $15 \mathrm{~m}$ of row. However, it is important to note that when by-plant grain yields were computed based on a fixed area (average distance between plants, $23.5 \mathrm{~cm}$, over the entire row), a $12.5 \times$ difference in yield differences was observed at the Ames, IA site (Fig. 5). At all sites, large differences in corn grain yield were observed over short distances whether or not grain yields were computed based on actual measured distances or an average (fixed) distance between plants.

At the Ames, IA site, midseason prediction of corn grain yields (same four-plant clusters) was quite good using NDVI collected at the V8 growth stage (Fig. 6). The average yield difference of $1996 \mathrm{~kg} \mathrm{ha}^{-1}$ between each four-plant cluster was greater than the precision at which final grain yields could be predicted midseason using NDVI (precision of $\pm 1565 \mathrm{~kg} \mathrm{ha}^{-1}$ ).

\section{Errors in Corn Grain Yields from Larger Scales}

Yet another alternative approach concerning this data was evaluating the errors associated with yield determined over fixed distances in a row (EFAW experiment station near Stillwater, OK; Shelton, NE; and Ames, IA). The distances used to calculate the yields were determined by dividing the total length of the row by the number of plants in the row. The yields were then averaged over multiples of that distance until the distance approached $1 \mathrm{~m}$. Then, the absolute value of the errors in estimating the by-plant corn yield from the average value of the yields along fixed distances were calculated. Table 4 shows the mean, minimum, and maximum error associated with the fixed-distance yield calculation. At each location, the errors in the by-plant yield prediction decreased as yields were averaged over greater distances, with errors approaching a constant as distances approached $1 \mathrm{~m}$ (Fig. 7). The distance where the true yield mean of the row could be estimated was between 0.5 to $0.6 \mathrm{~m}$. All sites behaved similarly, with similar normalized errors in the by-plant yield estimates. Even though there are errors associated with predicting yield at early growth stages (V8, Fig. 6), these errors in yield prediction were dwarfed in comparison to the byplant yield differences reported.

\section{REFERENCES}

Dobermann, A., J.L. Ping, V.I. Adamchuk, G.C. Simbahan, and R.B. Ferguson. 2003. Classification of crop yield variability in irrigated production fields. Agron. J. 95:1105-1120.

Lauer, J.G., and M. Rankin. 2004. Corn response to within row plant spacing variation. Agron. J. 96:1464-1468.

Lengnick, L.L. 1997. Spatial variation of early season nitrogen availability indicators in corn. Commun. Soil Sci. Plant Anal. 28:17211736.

Liu, W., M. Tollenaar, G. Stewart, and W. Deen. 2004. Within-row plant spacing variability does not affect corn yield. Agron. J. 96: 275-280.

Maddonni, G.A., and M.E. Otegui. 2004. Intra-specific competition in maize: Early establishment of hierarchies among plants affects final kernel set. Field Crops Res. 85:1-13.

Mallarino, A.P., E.S. Oyarzabal, and P.N. Hinz. 1999. Interpreting within-field relationships between crop yields and soil and plant variables using factor analysis. Precis. Agric. 1:15-25.

Nafziger, E.D., P.R. Carter, and E.E. Graham. 1991. Response of corn to uneven emergence. Crop Sci. 31:811-815.

Nielsen, R.L. 2001. Stand establishment variability in corn. Publ. AGRY-91-01. Purdue Univ., West Lafayette, IN.

Porter, P.M., J.G. Lauer, D.R. Huggers, E.S. Oplinger, and R.K. Crookston. 1998. Assessing spatial and temporal variability of corn and soybean yields. J. Prod. Agric. 11:359-363.

Raun, W.R., J.B. Solie, G.V. Johnson, M.L. Stone, R.W. Mullen, K.W. Freeman, W.E. Thomason, and E.V. Lukina. 2002. Improving nitrogen use efficiency in cereal grain production with optical sensing and variable rate application. Agron. J. 94:815-820.

Raun, W.R., J.B. Solie, G.V. Johnson, M.L. Stone, R.W. Whitney, H.L. Lees, H. Sembiring, and S.B. Phillips. 1998. Micro-variability in soil test, plant nutrient, and yield parameters in bermudagrass. Soil Sci. Soc. Am. J. 62:683-690.

Raun, W.R., J.B. Solie, K.L. Martin, K.W. Freeman, M.L. Stone, K.L. Martin, G.V. Johnson, and R.W. Mullen. 2005. Growth stage, development, and spatial variability in corn evaluated using optical sensor readings. J. Plant Nutr. 28:173-182.

Ritchie, S.W., J.J. Hanway, H.E. Thompson, and G.O. Benson. 1996. How a corn plant develops. Spec. Rep. 48. Rev. ed. Iowa State Univ. Coop. Ext. Serv., Ames.

Sadler, E.J., W.J. Busscher, P.J. Bauer, and D.L. Karlen. 1998. Spatial scale requirements for precision farming: A case study in the southeastern USA. Agron. J. 90:191-197.

SAS Institute. 2002. The SAS system for windows version 8.02. SAS Inst., Cary, NC.

Schmidt, J.P., A.J. DeJoia, R.B. Ferguson, R.K. Taylor, R.K. Young, and J.L. Havlin. 2002. Corn yield response to nitrogen at multiple in-field locations. Agron. J. 94:798-806.

Solie, J.B., W.R. Raun, and M.L. Stone. 1999. Submeter spatial variability of selected soil and bermudagrass production variables. Soil Sci. Soc. Am. J. 63:1724-1733.

Solie, J.B., W.R. Raun, R.W. Whitney, M.L. Stone, and J.D. Ringer. 1996. Optical sensor based field element size and sensing strategy for nitrogen application. Trans. ASAE 39(6):1983-1992.

Stone, M.L., J.B. Solie, W.R. Raun, R.W. Whitney, S.L. Taylor, and J.D. Ringer. 1996. Use of spectral radiance for correcting in-season fertilizer nitrogen deficiencies in winter wheat. Trans. ASAE 39(5):1623-1631.

Systat Software. 2000. TableCurve 2D, V5. Systat Software, Inc., Point Richmond, CA.

Taylor, S.L., M.E. Payton, and W.R. Raun. 1999. Relationship between mean yield, coefficient of variation, mean square error and plot size in wheat field experiments. Commun. Soil Sci. Plant Anal. 30:1439-1447.

Tollenaar, M., and J. Wu. 1999. Yield improvement in temperate maize is attributable to greater stress tolerance. Crop Sci. 39:1597-1604.

Varvel, G.E., J.S. Schepers, and D.D. Francis. 1997. Ability for inseason correction of nitrogen in corn using chlorophyll meters. Soil Sci. Soc. Am. J. 61:1233-1239.

Vega, C.R.C., and V.O. Sadras. 2003. Size-dependant growth and development of inequality in maize, sunflower, and soybean. Ann. Bot. 91:795-805. 